\title{
Hubungan Riwayat Penyakit Infeksi dan Pemberian ASI Eksklusif dengan Status Gizi Anak Usia 7-12 Bulan di Kecamatan Kelapa Lima Kota Kupang
}

\author{
Agung Dirgantara Namangboling,* Bhisma Murti,** Endang Sutisna Sulaeman ${ }^{* *}$ \\ *Program Magister Ilmu Gizi, ${ }^{*}$ Departemen Kesehatan Masyarakat Fakultas Kedokteran Universitas Sebelas Maret, Surakarta
}

Latar belakang. Adanya penyakit infeksi membuat kondisi kesehatan anak menurun sehingga berdampak pada nafsu makan dan akan mengurangi jumlah asupan makanannya dan zat gizi ke dalam tubuh. Pemberian ASI eksklusif dapat mencegah terjadinya diare yang disebabkan karena infeksi pada bayi serta dapat mempertahankan status gizi bayi.

Tujuan. Mengetahui hubungan antara riwayat penyakit infeksi, pemberian ASI eksklusif dan status gizi anak usia 7-12 bulan di Kupang, Nusa Tenggara Timur.

Metode. Penelitian analitik obsevasional dengan desain case control, dilakukan di Kecamatan Kelapa Lima Kota Kupang pada bulan April-Juli 2017. Subjek penelitian adalah anak usia 7-12 bulan, 116 anak dipilih dengan fixed disease sampling. Analisis data menggunakan uji chi square dan regresi logistik ganda.

Hasil. Hasil uji bivariat chi square menunjukkan adanya hubungan riwayat penyakit dengan status gizi (p;0,024) dan pemberian ASI eksklusif $(\mathrm{p} ; 0,026)$, sedangkan hasil regresi logistik ganda, riwayat penyakit infeksi merupakan faktor dominan penentu status gizi pada anak usia 7-2 bulan di Kecamatan Kelapa Lima Kota Kupang (p;0,025 dengan OR;2,38 dan CI;1,11-5,08).

Kesimpulan. Terdapat hubungan yang bermakna antara riwayat penyakit infeksi dan pemberian ASI eksklsuif dengan status gizi. Riwayat penyakit infeksi adalah faktor dominan penentu status gizi anak usia 7-12 bulan. Sari Pediatri 2017;19(2):91-6

Kata kunci: status gizi, penyakit infeksi, ASI eksklusif, anak usia 7-12 bulan

\section{Association between Infectious Diseases History, Exclusive Breastfeeding, and Nutritional Status in Children Aged 7-12 Month in Kelapa Lima Subdistrict Kupang}

Agung Dirgantara Namangboling,* Bhisma Murti,** Endang Sutisna Sulaeman ${ }^{* *}$

Background. The infectious disease of presence to make decreased health condition in children so that impact on appetite and will reducing amount of food intake and nutriens into the body. Exclusive breastfeeding prevented diarrhea which caused by infectious in child and can be defend of nutritional status in children.

Objective. This study aimed to investigate association between infectious diseases history, exclusive breastfeeding and nutritional status in children aged 7-12 months in Kupang, East Nusa Tenggara.

Method. This was an analytic abservational study with case control design. The study was conducted in Kelapa Lima subdistrict, Kupang, East Nusa Tenggara, from April to June 2017. A sample of 116 children age 7-12 months was selected using fixed disease sampling. The data was analyzed using chi square test and multiple logistic regression.

Results. Infectious disease history $(\mathrm{OR}=2.38 ; 95 \% \mathrm{CI}=1.11-5.08 ; \mathrm{p}=0.024)$ and exclusive breastfeeding $(\mathrm{OR}=2.32 ; 95 \% \mathrm{CI}=1.10$ 4.905; $\mathrm{p}=0.026$ ) were associated with better nutritional status (weigh for height) in children and infectious diseases history was dominant factor determining of nutritional status in children aged 7-2 months in Kecamatan Kelapa Lima subdistrict, Kupang, East Nusa Tenggara $(\mathrm{OR}=2.38$; 95\% CI=1.11-5,08; p: 0.025).

Conclusion. Infectious diseases history, exclusive breastfeeding are associated with nutritional status and infectious diseases history are the dominant factors and determining of nutritional status in children aged 7-12 month. Sari Pediatri 2017;19(2):91-6

Keywords: nutritional status, infectious diseases history, exclusive breastfeeding, children aged 7-12 months.

Alamat korespondensi: Agung Dirgantara Namangboling. Program Magister Ilmu Gizi Universitas Sebelas Maret. Jl. Ir. Sutami 36 A, Kentingan, Surakarta 57126 , Indonesia. e-mail : akomang46@gmail.com 
$\mathrm{M}$ asalah gizi dapat menjadi suatu ancaman bagi kelangsungan hidup suatu bangsa. ${ }^{1}$ Status gizi tiap individu menunjukkan kebutuhan fisiologis individu itu sendiri karena jika tidak terpenuhi maka akan menimbulkan masalah kesehatan yang berkaitan dengan gizi. ${ }^{2}$ Kondisi kesehatan dan gizi pada anak merupakan hal yang saling berpengaruh. Status gizi anak juga dipengaruhi oleh banyak faktor seperti aspek konsumsi, kesehatan anak, pengasuhan psikososial. ${ }^{3}$ Dengan adanya penyakit infeksi maka kondisi kesehatan anak menurun sehingga berdampak pada nafsu makan dan akan mengurangi jumlah asupan makanannya, sehingga kurangnya zat gizi yang masuk kedalam tubuh. Penyakit infeksi seperti diare, pneumonia, dan malaria adalah penyebab sebagian besar kematian. Setengah dari 5,9 juta anak balita meniggal karena penyakit infeksi. ${ }^{4}$ Dampak lain dari infeksi adalah muntah-muntah dan diare yang menyebabkan kurangannya zat gizi dan cairan dalam tubuh. ${ }^{5}$

Pemberian ASI eksklusif dapat mencegah terjadinya diare yang disebabkan karena infeksi pada bayi serta dapat mempertahankan status gizi bayi, karena ASI merupakan makanan terbaik dengan zat gizi lengkap dan sangat bagus untuk kebutuhan bayi dalam pertumbuhan dan perkembangannya. ${ }^{6}$ Pemberian ASI yang dilakukan secara eksklusif mampu mengurangi prevalensi kejadian kurang gizi pada anak. ${ }^{7}$ Promosi ASI dianggap sebagai intervensi yang bertujuan untuk mempertahankan status gizi, derajat kesehatan tiap individu, dan bisa mengurangi angka kematian sebesar $8 \%$ secara global. ${ }^{8}$

Menurut Dinas Kesehatan Provinsi NTT tahun 2015, cakupan pemberian ASI eksklusif di Provinsi Nusa Tenggara Timur mencapai $77,0 \%$ sehingga belum mencapai angka target Nasional. ${ }^{10}$ Cakupan pemberian ASI eksklusif pada tahun 2015 di Kota Kupang hanya mencapai $53,4 \%$ dengan penyakit utama terbanyak adalah ISPA $37,4 \%$ dan kasus gizi buruk yang ditemukan sebanyak 204 kasus. Kecamatan Kelapa Lima merupakan kecamatan dengan cakupan pemberian ASI eksklusif terendah di Kota Kupang dan mempunyai kasus gizi buruk terbanyak di tahun 2015.? Tujuan pada penelitian ini adalah untuk mengetahui hubungan antara riwayat penyakit infeksi anak dan pemberian ASI eksklusif dengan status gizi anak usia 7-12 bulan di Kecamatan Kelapa Lima Kota Kupang.

\section{Metode}

Penelitian ini dilakukan di Kecamatan Kelapa Lima Kota Kupang, Nusa Tenggara Timur pada bulan April-Juli 2017. Jenis penelitian ini adalah analitik observasional dengan desain Case Control karena ingin melihat pengaruh riwayat penyakit infeksi dan pemberian ASI eksklusif terhadap status gizi pada anak 7-12 bulan. Total sampel dalam penelitian ini adalah sebanyak 116 sampel dan metode pengambilan sampel yang digunakan adalah fixed disease sampling. Variabel dependen pada penelitian ini adalah status gizi dan veriabel independen adalah riwayat penyakit infeksi dan pemberian ASI eksklusif. Data mengenai riwayat penyakit dan pemberian ASI eksklusif diperoleh dengan wawancara mengunakan kuesioner dan status gizi diukur dengan indikator berat badan/ panjang badan menggunakan baby scale dan microtoise. Berdasarkan klasifikasi dari WHO maka sampel dibagi dalam dua kelompok yaitu kelompok kasus dengan status gizi kurus s/d sangat kurus $(<-2 S D$ s/d < -3SD) dan kelompok kontrol dengan status gizi normal s/d gemuk (-2SD s/d > 2SD). Uji statistik chi-square digunakan pada analisis bivariat sedangkan pada analisis multivariat menggunakan uji regresi logistik ganda dengan program SPSS versi 16 untuk mengetahui hubungan antara riwayat penyakit infeksi dan pemberian ASI eksklusif dengan status gizi dengan nilai $\mathrm{p}$ sebesar 0,05 .

\section{Hasil}

Terdapat 31 anak dengan status gizi kurus dan sangat kurus berjenis kelamin perempuan yang masuk pada kelompok kasus. Sampel pada kelompok kontrol 33 anak dengan status gizi normal dan gemuk berjenis kelamin laki-laki. Total sampel, anak dengan jenis kelamin laki-laki merupakan jumlah terbanyak, yaitu $60(52 \%)$ dan sisanya perempuan $56(48 \%)$ anak.

Sebanyak 34,5\% anak pada kelompok kasus mempunyai riwayat penyakit, sementara pada kelompok kontrol $24,1 \%$ dan $31,9 \%$ anak pada kelompok kasus tidak mendapat ASI eksklusif, sedangkan dan pada kelompok kontrol 21,6\%. 
Agung Dirgantara Namangboling dkk: Riwayat penyakit infeksi dan pemberian ASI eksklusif dengan status gizi anak usia 7-12 bulan

Tabel 1. Karakteristik sampel penelitian

\begin{tabular}{lcccccc}
\hline Gambaran riwayat penyakit infeksi sampel & & & & \\
\hline & Ada riwayat penyakit & $\%$ & $\begin{array}{c}\text { Tidak ada riwayat } \\
\text { penyakit }\end{array}$ & $\%$ & $\mathrm{n}$ & $\%$ \\
\hline Kasus & 40 & 34,5 & 18 & 15,5 & 58 & 50 \\
Kontrol & 28 & 24,1 & 30 & 25,9 & 58 & 50 \\
Total & 68 & 58,6 & 48 & 41,4 & 116 & 100 \\
\hline
\end{tabular}

Tabel 2. Gambaran pemberian ASI eksklusif pada sampel

\begin{tabular}{lcccccc}
\hline Status gizi & $\begin{array}{c}\text { Mendapat ASI } \\
\text { eksklusif }\end{array}$ & $\%$ & $\begin{array}{c}\text { Tidak } \\
\text { mendapat ASI } \\
\text { eksklusif }\end{array}$ & $\%$ & $\mathrm{n}$ & $\%$ \\
\hline Kasus & 21 & 18,1 & 37 & 31,9 & 58 & 50 \\
Kontrol & 33 & 28,4 & 25 & 21,6 & 58 & 50 \\
Total & 54 & 46,6 & 62 & 53,4 & 116 & 100 \\
\hline
\end{tabular}

Tabel 3. Hasil analisis bivariat dengan uji chi square

\begin{tabular}{lcccccc}
\hline Status gizi & $\begin{array}{c}\text { Ada riwayat } \\
\text { penyakit }\end{array}$ & $\%$ & $\begin{array}{c}\text { Tidak ada riwayat } \\
\text { penyakit }\end{array}$ & $\%$ & $\begin{array}{c}\text { OR } \\
\text { CI 95\% }\end{array}$ & p \\
\hline Kasus & 40 & 34,5 & 18 & 15,5 & 2,38 & 0,024 \\
Kontrol & 28 & 24,1 & 30 & 25,9 & $(1,11-5,08)$ & \\
\hline
\end{tabular}

Tabel 4. Hasil analisis bivariat dengan uji chi square

\begin{tabular}{lcccccc}
\hline Status Gizi & $\begin{array}{c}\text { Mendapat ASI } \\
\text { eksklusif }\end{array}$ & $\%$ & $\begin{array}{c}\text { Tidak mendapat } \\
\text { ASI eksklusif }\end{array}$ & $\%$ & $\begin{array}{c}\text { OR } \\
\text { CI 95\% }\end{array}$ & p \\
\hline Kasus & 21 & 18,1 & 37 & 31,9 & 2,32 & 0,026 \\
\hline Kontrol & 33 & 28,4 & 25 & 21,6 & $(1,10-4,90)$ & \\
\hline
\end{tabular}

Hasil analisis bivariat hubungan riwayat penyakit dengan status gizi anak menunjukkan bahwa dari 58 anak pada kelompok status gizi kurus dan sangat kurus (kasus) terdapat 40 (34,5\%) anak yang mempunyai riwayat penyakit. Pada kelompok status gizi normal dan gemuk (kontrol) terdapat $28(24,1 \%)$ anak yang mempunyai riwayat penyakit dari 58 anak. Dari analisis diperoleh nilai signifikan $\mathrm{p}=0,024$ dengan OR:2,38 dan CI:1,11-5,08. Karena nilap p lebih kecil dari 0,05 maka secara statistik terdapat hubungan yang bermakna antara riwayat penyakit dan status gizi pada anak usia 7-2 bulan di Kecamatan Kelapa Lima Kota Kupang. Dari hasil ini dapat dikatakan bahwa riwayat penyakit infeksi seperti diare dan ISPA di Kecamatan Kelapa Lima Kota Kupang sangat berpengaruh terhadap status gizi anak dikarenakan adanya penurunan nafsu makan.

Hasil analisis bivariat hubungan pemberian ASI eksklusif dan status gizi menunjukkan bahwa dari 58 anak dengan kategori status gizi kurus dan sangat kurus (kasus) yang tidak mendapat ASI secara eksklusif adalah $37(31,9 \%)$ anak. Sementara pada status gizi normal dan gemuk (kontrol) adalah $25(21,6 \%)$ anak yang tidak mendapatkan ASI secara eksklusif. Dari hasil analisis diperoleh nilai signifikan $\mathrm{p}=0,026$ dengan OR:2,32 dan CI:1,10-4,90. Karena nilai p lebih kecil dari 0,05 maka secara statistik terdapat hubungan yang bermakna antara pemberian ASI eksklusif dengan status gizi pada anak usia 7-12 bulan di Kecamatan Kelapa Lima Kota Kupang. 
Hasil uji regresi logistik ganda menunjukkan variabel yang paling dominan berhubungan serta mempunyai pengaruh terhadap status gizi adalah riwayat penyakit infeksi ( $\mathrm{p}=0,025$ dengan OR:2,38 dan CI;1,11-5,08). Pada variabel pemberian ASI eksklusif, hasil multivariat yang diperoleh adalah $\mathrm{p}=0,113$ dengan OR:1,89 dan CI:0,86-4,17. Dari total sampel, $58,6 \%$ anak yang mempunyai riwayat penyakit infeksi, seperti diare dan ISPA, masuk dalam kelompok sampel dengan kategori status gizi kurus dan sangat kurus. Hal ini disebabkan karena pemahaman orang tua yang rendah mengenai higiene dan sanitasi serta pentingnya kebersihan lingkungan sekitar terhadap kesehatan anak. Dari hasil wawancara kepada responden didapatkan informasi bahwa ratarata sampel dengan kasus diare terbanyak adalah sampel dengan pendapatan orang tua rendah dan tingkat kebersihan rumah tangga jauh dari yang diharapkan.

\section{Pembahasan}

Kejadian penyakit infeksi yang tinggi, seperti diare dan ISPA, terhadap sampel di Kecamatan Kelapa Lima disebabkan karena kesadaran orang tua yang kurang akan pentingnya higiene dan sanitasi terhadap asupan gizi bagi anak. Pemahaman orang tua juga kurang dalam mempersiapkan kebutuhan pangan rumah tangga. Selain itu, penyebaran bakteri dan virus juga ditularkan melalui media atau orang-orang terdekat dari subjek penelitian. Faktor lingkungan, seperti sarana air yang tidak bersih juga menjadi penyebab terjadinya diare dan penyakit infeksi. ${ }^{12}$ Pada penelitian kami, sebagian besar anak di Kota Kupang, khususnya wilayah Kecamatan Kelapa Lima, mengalami masalah gizi akibat paparan virus maupun bakteri sehingga berisiko terkena penyakit infeksi dan berdampak terhadap penurunan berat badan dan hilangnya nafsu makan anak.

Rata-rata di wilayah pedesaan, sanitasi yang buruk di lingkungan rumah tangga relatif banyak ditemukan sehingga penyakit infeksi sangat mudah untuk menyerang bayi dan balita yang menyebabkan kurangnya asupan gizi. ${ }^{13}$ Penelitian yang dilakukan terhadap balita di Kota Padang melaporkan bahwa status gizi kurang lebih banyak terjadi pada balita diare dibangdingkan dengan balita yang tidak diare. ${ }^{14} \mathrm{Hal}$ yang sama juga dilaporkan di Kabupaten
Tasikmalaya, bahwa anak dengan gizi kurang memiliki riwayat penyakit infeksi, seperti diare berulang, ISPA berulang, dan tuberkolusis. ${ }^{15}$ Dalam penelitian lain dilaporkan terdapat hubungan antara riwayat penyakit infeksi dengan status gizi anak balita. Laporan tersebut menyatakan bahwa penyakit infeksi sangat berpengaruh terhadap status gizi balita. Anak yang mendapat makan cukup tetapi sering terserang penyakit infeksi juga dapat menderita kekurangan energi protein (KEP) serta terdapat hubungan antara riwayat diare dengan status gizi anak balita. ${ }^{16}$ Gizi kurang dapat menghambat reaksi imunologis terhadap infeksi penyakit tertentu seperti diare. Pada kondisi berat, anak sering ditemukan dengan status gizi buruk seperti kwashiorkor atau marasmus. Infeksi berat juga membuat tubuh anak kehilangan energi serta kurangnya cairan tubuh akibat muntah dan diare. ${ }^{17}$

Jika dilihat pada kelompok kasus, anak yang tidak mendapat ASI eksklusif lebih banyak jumlahnya dari pada yang mendapat ASI eksklusif. Bila dilihat dari penambahan berat badan, sampel kelompok kasus yang tidak mendapat ASI eksklusif mempunyai penambahan berat badan yang kurang dari ratarata. Bahkan, terdapat juga sampel yang mengalami penurunan berat badan selama 2 bulan terakhir. Ratarata perilaku pemberian ASI secara eksklusif lebih cenderung terhadap ibu dengan usia 25-30 tahun karena kemampuan menyusui setiap wanita berbeda. Pada umumnya, kemampuan menyusui pada wanita usia muda jauh lebih baik dari pada wanita yang lebih tua dalam memberikan ASI kepada anaknya. ${ }^{18}$ $\mathrm{Hal}$ ini justru sesuai dengan kondisi yang terjadi di lokasi penelitian karena sekitar $\pm 50 \%$ responden yang memberikan ASI secara eksklusif kepada anaknya adalah berusia $<25$ tahun. Sementara pada responden dengan usia $>35$ tahun beberapa di antaranya tidak memberikan ASI secara eksklusif dengan alasan tertentu. Penelitian di Yogyakarta melaporkan bahwa status gizi pada anak usia 6-24 bulan dipengaruhi oleh pola pemberian ASI karena ASI berperan dalam proses pertumbuhan anak. ${ }^{19}$

Asupan makanan sesorang berpengaruh terhadap status gizi orang tersebut. Kurang gizi maupun gizi lebih diakibatkan karena tubuh mengalami kekurangan atau kelebihan zat gizi. ${ }^{20}$ Pemberian ASI eksklusif akan membuat status gizi anak bertambah baik dalam usia 6-24 bulan dari pada anak yang tidak mendapat ASI secara eksklusif. ${ }^{21}$ Hasil penelitian di Buleleng melaporkan bahwa ada hubungan antara pemberian 
ASI eksklusif dengan status gizi balita usia 6-24 bulan. Ibu yang memberikan ASI secara eksklusif kepada anaknya akan semakin baik status gizi anaknya jika dibandingkan dengan ibu yang tidak memberikan ASI secara eksklusif kepada anaknya. ${ }^{21}$

Hasil penelitian di Padang Pasir Kota Padang melaporkan bahwa tidak terdapat hubungan antara pemberian ASI eksklusif dengan status gizi bayi dikarenakan jumlah bayi yang diberi ASI eksklusiflebih sedikit dari bayi yang tidak diberikan ASI eksklusif. ${ }^{22}$ Dan penelitian di Jakarta, juga melaporkan tidak terdapat hubungan antara pemberian ASI eksklusif dengan status gizi. Keberhasilan dalam pemberian ASI juga dipengaruhi oleh beberapa faktor, seperti sosial budaya, dukungan suami atau keluarga, dukungan petugas kesehatan, kesehatan ibu, status pekerjaan ibu, tingkat pendidikan dan pengetahuan ibu. ${ }^{23}$ Dengan demikian, pemberian ASI eksklusif di Kecamatan Kelapa Lima Kota Kupang bukanlah salah satu faktor utama penentu status gizi anak usia 7-12 bulan karena masih ada faktor lain, seperti pegetahuan gizi ibu, tingkat pendidikan ibu, pendapatan orang tua, waktu asuh dan status pekerjaan ibu. Namun, dalam penelitian kami, riwayat penyakit infeksi merupakan faktor yang paling dominan atau berpengaruh besar terhadap status gizi anak usia 7-12 bulan di Kecamatan Kelapa Lima Kota Kupang dari pada pemberian ASI eksklusif.

\section{Kesimpulan}

Riwayat penyakit infeksi dan pemberian ASI eksklusif mempunyai hubungan yang bermakna dengan status gizi anak 7-12 bulan dan riwayat penyakit infeksi merupakan faktor paling dominan yang dapat menyebabkan terjadinya masalah gizi pada anak usia 7-12 bulan di Kecamatan Kelapa Lima Kota Kupang dengan peluang sebesar 2,38 kali.

\section{Daftar pustaka}

1. Burhani PA, Oenzil F, Revila G. Hubungan tingkat pengetahuan ibu dan tingkat ekonomi keluarga nelayan dengan status gizi balita di Kelurahan Air Tawar Barat Kota Padang. Jurnal Kesehatan Andalas 2015;3:515-21.

2. Adriani M, Wirjatmadi B. Peranan gizi dalam siklus kehidupan. Jakarta: Kencana Prenada Media Grup.; 2014.

3. Martianto D, Riyadi H, Hastuti D, Briawan D. Ketersediaan konsumsi pangan dan status gizi di Kabupaten Lembata, Provinsi NTT. Bogor: Fakultas Ekologi Manusia, Departemen Gizi Masyarakat. Institut Pertanian Bogor: 2006.

4. Khan AM, Zulfiqar AB. Childhood infectious diseases. overview. reference module in biomedical sciences. International Encyclopedia of Public Health Second Edition 2017:517-38.

5. Moehji S. Ilmu gizi 2, penanggulangan gizi buruk. Jakarta: Papas Sinar Sinanti; 2003.

6. Ida. Faktor-faktor yang berhubungan dengan pemberian ASI Eksklusif 6 bulan di wilayah kerja Puskesmas Kemiri Muka Kota Depok Tahun 2011. (tesis). Depok : Fakultas Kesehatan Masyarakat. Universitas Indonesia, 2012.

7. Kamudoni P, Maleta K, Shi Z, Holmboe-Ottesen G. Exclusive breastfeeding duration during the first 6 months of life is positively associated with length-for-age among infants 6-12 months old, in Mangochi District, Malawi. Eur J Clin Nutr 2015;69:96-101.

8. Lars T. Fadnes, Victoria N, Ingunn ME, dkk. Effects of an exclusive breastfeeding intervention for six months on growth patterns of 4-5 years old children in Uganda. BMC Public Health 2016;16:555.

9. Dinas Kesehatan Kota Kupang. Profil Kesehatan Kota Kupang Tahun 2015. Kupang: Dinkes; 2015.

10. Dinas Kesehatan Provinsi Nusa Tenggara Timur. Laporan Seksi Perbaikan Gizi Provinsi Nusa Tenggara Timur. Kupang: Dinkes Provinsi NTT; 2015.

11. Suhardjo. Perencanaan pangan dan gizi. Jakarta: Bumi Aksara; 2013.

12. Adisasmito W. Faktor resiko diare pada bayi dan balita indonesia: systematic review penelitian akademik bidang kesehatan masyarakat. Makara Kesehatan 2007;11:1-10.

13. Rosha BC, Hardinsyah, Baliwati YF. Determinan analysis of stunting children aged 0-23 months in poor areas in central and east java. J Nutrotional and Food Res 2012;35:34-41.

14. Rosari A, Rini EA, Masrul. Hubungan diare dengan status gizi balita di Kelurahan Lubuk Buaya Kecamatan Koto Tangah Kota Padang. Jurnal Kesehatan Andalas 2013;2:111-5.

15. Fatimah S, Nurhidayah I, Rakhmawati W. Faktor-faktor yang berkontribusi terhadap status gizi pada balita di Kecamatan Ciawi Kabupaten Tasikmalaya. Majalah Keperawatan Unpad 2008;10:37-51.

16. Ihsan M, Hiswani, Jemadi. Faktor-faktor yang berhubungan dengan status gizi anak balita di Desa Teluk Rumbia Kecamatan Singkil Kabupaten Aceh Singkil Tahun 2012. Jurnal Gizi Kesehatan Reproduksi dan Epidemiologi 2013;2: 1-10. 
17. Santoso S, Ranti AL. Kesehatan dan gizi. Jakarta: Rineka Cipta; 2013.

18. M Yamin. Faktor-faktor yang berhubungan dengan pemberian ASI eksklusif oleh ibu bayi yang berumur 6-12 bulan di Kecamatan Metro Timur Kota Metro Lampung. (tesis) Depok: Fakultas Kesehatan Masyarakat. Universitas Indonesia, 2007.

19. Septiana R, Djannah SN, Djamil DM. Hubungan antara pola pemberian makanan pendamping ASI (MP-ASI) dan status gizi balita usia 6-24 bulan di wilayah kerja Puskesmas Gedongtengen Yogyakarta. Jurnal Kes Mas 2010;4:76-143.

20. Loaloka MS. Hubungan pengetahuan gizi ibu dan pola pemberian MP-ASI dengan perkembangan motorik pada anak stunting usia 12-24 bulan di Kota Kupang. (tesis)
Surakarta : Pascasarjana Prodi Ilmu Gizi. Universitas Sebelas Maret, 2016.

21. Giri MKW, Muliarta IW, Wahyuni NPDS. Hubungan pemberian ASI eksklusif dengan status gizi balita usia 6-24 bulan Di Kampung Kajanan, Buleleng. Jurnal Sains dan Teknologi 2013;2:184-92.

22. Nilakesuma A, Jurnalis YD, Rusdji SR. Hubungan status gizi dengan pemberian ASI eksklusif, tingkat pendidikan ibu dan status ekonomi keluarga di wilayah kerja Puskesmas Padang Pasir. Jurnal Kesehatan Andalas 2015;4:37-44.

23. Adelina N. Status gizi bayi usia 1,5-8 bulan dan faktor-faktor yang berhubungan di Jakarta Selatan. (skripsi) Jakarta : Fakultas Kedokteran. Universitas Indonesia, 2009. 